\title{
The Travel Ban: Affected Mathematicians Tell Their Stories
}

\author{
Alexander Diaz-Lopez, Allyn Jackson, and Stephen Kennedy
}

On Friday, January 27, 2017, Donald Trump signed Executive Order 13769 banning entry into the United States by citizens of seven Middle Eastern nations. Innocent people were detained and expelled; families were divided; chaos, confusion, and discord were widespread. On Monday, January 30, the AMS Trustees issued a statement opposing the ban (see sidebar on page 680). Notices sought out individuals directly affected by the ban, and we report their stories here. The publication schedule of Notices undoubtedly means that these colleagues' situations will have changed by the time their stories appear in print.

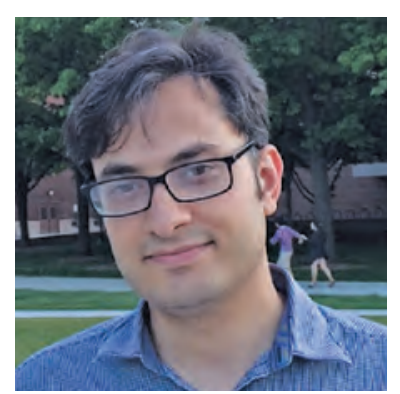

Hamed Razavi, a recent

Michigan PhD and an Iranian citizen, was from returning to Ann Arbor to collect the Sumner Myers Prize. prevented by the ban

Hamed Razavi is a postdoctoral researcher at the biorobotics laboratory of the École Polytechnique Fédérale de Lausanne (EPFL), Switzerland. Razavi is an Iranian citizen with a bachelor's degree in mathematics and mechanical engineering and a master's in the latter discipline from Shiraz University. He came to the United States in 2010 and earned a PhD from the University of Michigan in applied mathematics in 2016.

Razavi works in control theory. In his thesis, he developed a mathematical theory to design algorithms for stable periodic walking of legged robots. His work at EPFL is focused on implementing that theory. His $\mathrm{PhD}$ thesis was awarded Michigan's Sumner Myers Prize for the best mathematics dissertation of 2016. That prize was to be awarded this spring at a ceremony in Ann Arbor at which Razavi

The authors are Notices editors. Their e-mail addresses are adiaz1o1@swarthmore.edu, axj@ams.org, and skennedy@ carleton. edu.

For permission to reprint this article, please contact:

reprint-permission@ams .org.

DOI: http://dx.doi.org/10.1090/noti1548 would describe his work. His visa application to attend that ceremony was in process when the executive order was issued. The uncertainty about his ability to enter the US forced him to deliver the lecture and receive his prize via a livestream from Lausanne on March 24.

Major conferences in Razavi's field are regularly held in the United States; he assumes that these are now closed to him. He had considered academic employment in the United States at the conclusion of his current postdoctoral position but assumes this option is also closed to him.

Razavi's main concern is not his own future. He is more worried about younger Iranian and Middle Eastern would-be mathematicians and scientists who will not have the opportunity for US visits and educations. He is worried about the people in the United States who might, with no warning, be cut off from families and friends again. He

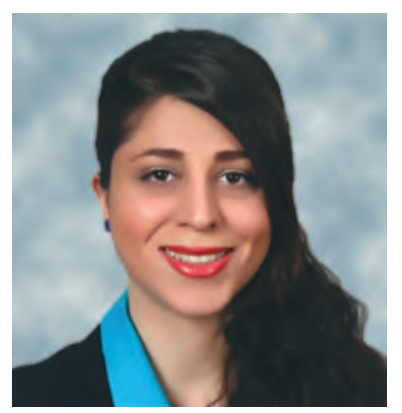

Beheshteh Tolouei Rakhshan is a graduate student at Purdue. Her Iranian fiancé is unable to join her in the United States. points too to the damage being done to the reputation and practice of US science, saying, "It is not only about the specific people that the travel ban has affected, it is also about the atmosphere that it has generated which could negatively affect the US status in science."

Beheshteh Tolouei Rakhshan, originally from Iran, has been a PhD student in applied mathematics at Purdue University since the fall of 2016. Because she has multiple sclerosis, she must try to avoid 
strong mental pressure and stress, which can seriously affect her physical well-being.

Since November 2013 she has been engaged to an Iranian man. The two studied at the same university in Iran and together began the application process for further study in the United States. She was accepted at Purdue, and he was accepted in applied mathematics at Georgia State University. Although they would be geographically separated, they resolved to meet every chance they could. This resolution helped Rakhshan both emotionally and physically to have the strength she needed for her studies.

Rakhshan received her F1 Visa at the United States embassy in Armenia. However, her fiancé's five visa applications were denied under Section 214(b), meaning that he did not demonstrate sufficiently strong and long-term ties outside the United States. The denials all occurred before the executive order. Now, with the executive order in place, the young couple fear they will never be able to carry out their plans. Unable to see her fiancé or her family, Rakhshan is considering leaving the United States to continue her education elsewhere. This would not be an easy decision, since she worked hard in Iran to save enough money to come to the United States and realize her educational goals. Her illness, together with the emotional stress she has endured, have left her without the concentration needed for her mathematical work.

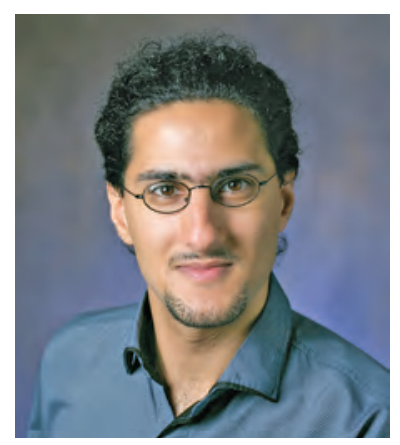

Nima Rasekh is a graduate student at Illinois. His wife was trapped outside the country by the travel ban.

Nima Rasekh is a fourthyear graduate student at the University of Illinois at Urbana-Champaign studying homotopy theory, specifically higher category theory. Rasekh is an Iranian citizen who spent his childhood in Germany and attended high school and university in Shiraz, Iran. Rasekh spent one year at the University of Western Ontario, earning a master's degree, before moving to the United States and UIUC in fall 2013.

On the day that the travel ban was issued, Rasekh's wife, an Iranian citizen with a valid US Visa, was in Iran visiting family. The ban would prevent her from returning. He describes his life and state of mind as "completely upended" as he contemplated finishing his studies apart from her for he knew not how long. The stress and uncertainty made it difficult to work. When Judge Robarts of the district court stayed the executive order, Rasekh immediately bought a plane ticket for his wife to return, and, fortunately, she made it home. "The other lasting effect is that it just makes doing math more difficult, as I am now forced to spend a portion of every day to read news and see whether there

is another executive order that will significantly affect my life," he said.

Rasekh plans to graduate next year and hopes for a postdoc with a strong homotopy theory group. He feels reasonably secure about being able to stay in the United States to finish his degree. But he has decided that he must focus his job search outside the United States given the uncertainty of his status here. He points out the logistical difficulty of looking for a job outside the country while simultaneously being unable to leave the country because of possible difficulty in returning. For that same reason he has stopped considering conference travel outside the United States.

Rasekh stresses that he doesn't feel that he has been particularly harmed by the ban. He is more worried about others: refugees in dire danger being denied safety, other foreigners being denied the educational opportunities he has enjoyed. He worries too about the misconceptions in the United States that lead to such policies. "There seem to be a lot of misunderstandings in this society when it comes to Iranian or in general Middle Eastern people," he said. "I was hoping I could play a part in changing these conceptions."

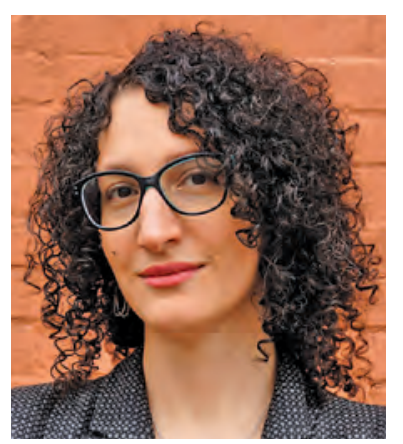

Camelia Karimianpour is a postdoc at Michigan whose sister was stranded in Tehran after attending their father's funeral.

branching rules and minimal degree problems."

Karimianpour is concerned about her ability to travel outside the United States. She believes it would be "very risky" to leave the United States, though she had been anticipating traveling for conferences and collaborations to both Canada and Europe.

Much of Karimianpour's family remains in Tehran. She now feels unable to visit them, and, of course, they cannot visit her. She has a sister and brother-in-law who live in Philadelphia. In November of last year Karimianpour and her sister traveled to Iran for their father's funeral. Karimianpour returned to the United States before the ban was put in place, but her sister remained behind in Iran for an 


\section{"long-term \\ effect [on] the way mathematicians, and science in general, progress" \\ -C. Karimianpour}

extended visit. As of this writing, Karimianpour's sister remains stranded in Tehran, unable to return home to Philadelphia, because embassies will not schedule appointments to renew visas for citizens of the seven countries excluded by the ban.

As was the case with every affected mathematician with whom we talked, Karimianpour was more concerned about the effect on others and on mathematics itself than she was about her own situation. "I think we all know the progress of math benefits enormously from bright mathematicians regardless of their race, religion, or nationality. There is no doubt that limiting the access of certain bright minds to some of the elite institutions of mathematics will have a long-term effect [on] the way mathematicians, and science in general, progress." She cited two specific potential harms. First, talented young foreign mathematicians, who already have to separate from their families and friends and endure an arduous and extreme visa process, might be less willing to do that

\section{AMS Council Statement on Immigration}

The Council reaffirms its policy on immigration ${ }^{2}$, adopted in March of 1997.

Mathematical sciences profit enormously from unfettered contact between colleagues from all over the world. The United States is a destination of choice for international students who wish to study mathematics; the US annually hosts many conferences attracting global participation. Our nation's position of leadership in mathematics depends critically upon open scientific borders. We urge our colleagues to support efforts to maintain the international collegiality, openness, and exchange that strengthens the vitality of the mathematics community, to the benefit of our nation and the world.

Note: This Statement was adopted by the AMS Council in April 2017.

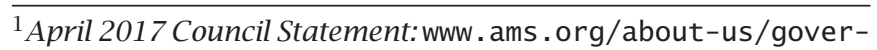
nance/policy-statements/statements-immigration-0417

${ }^{2}$ March 1997 AMS Policy Statement: www.ams.org/about-us/ governance/policy-statements/sec-immigration

${ }^{3}$ Board of Trustees Statement: www . ams . org/news?news_id=3305

${ }^{4}$ Academics Petition: https://notoimmigrationban.com/
}

to face a tenuous future in the United States. And second, foreign mathematicians who are unaffected by the ban might just decide, either out of solidarity or a desire to avoid mistreatment at the border, to avoid scientific travels to the United States.

\section{Photo Credits}

Photo of Hamed Razavi is courtesy of Hamed Razavi.

Photo of Beheshteh Tolouei Rakhshan is courtesy of Illia Photo and Film Studio.

Photo of Nima Rasekh is courtesy of Nima Rasekh.

Photo of Camelia Karimianpour is courtesy of Camelia Karimianpour.

\section{Statement by AMS Board of Trustees}

The members of the Board of Trustees of the American Mathematical Society wish to express their opposition to the Executive Order signed by President Trump that temporarily suspends immigration benefits to citizens of seven nations.

For many years, mathematical sciences in the USA have profited enormously from unfettered contact with colleagues from all over the world. The United States has been a destination of choice for international students who wish to study mathematics; the US annually hosts hundreds of conferences attracting global participation. Our nation's position of leadership in mathematics depends critically upon open scientific borders. By threatening these borders, the Executive Order will do irreparable damage to the mathematical enterprise of the United States.

We urge our colleagues to support efforts to maintain the international collegiality, openness, and exchange that strengthens the vitality of the mathematics community, to the benefit of everyone.

We have all signed the online petition of academics ${ }^{4}$ opposing the ban. We encourage our colleagues to consider joining us in signing it and in asking the Administration to rescind the Executive Order.

Robert Bryant, president of the AMS

Kenneth Ribet, president-elect of the AMS

Ruth Charney

Ralph Cohen

Jane Hawkins

Bryna Kra

Robert Lazarsfeld

Zbigniew Nitecki

Joseph Silverman

Karen Vogtmann

Note: The AMS Board of Trustees made this statement on January 30, 2017, while Robert Bryant was AMS president. Bryant's presidential term ended two days later; he was succeeded by Kenneth Ribet. 